\title{
Holistic Development of Human Talent - Leveraging On E- Maarah Tuition Program through the Network of Mosque (Nom)
}

\author{
Abdul Rahman Ahmad Dahlan, Anis Suraya binti Songib, Rabi'atul Adawiyah \\ binti Ismail, Amilia binti Mohd Mokhtar, Nor Shahidah binti Moktar@Mokhtar \\ Kulliyyah of Information \& Communication Technology \\ International Islamic University Malaysia
}

\begin{abstract}
Education is an essential process for every human being especially school children. However, parents are more concern with their children's Intelligent Quotient (IQ) achievement, neglecting or less focus on the Emotional Quotient (EQ) and Spiritual Quotient (SQ) achievement. This paper intends to propose a conceptual solution that provides a holistic development of school children focusing on $I Q, E Q$, and $S Q$ with 'ukhrawi' (or Hereafter) elements. The paper is based on literature review, real world observations and adopting business model canvas (BMC) framework in building a conceptual solution for holistic development of human talent. This paper explores the opportunity of providing holistic and balanced education to school children by leveraging the network of mosques just like what the Prophet Muhammad's PBUH used to do during his time, and at the same time generating sustainable revenue and profit utilizing technology-based solution. The findings of this paper show that cyber world, through the creative use of ICT and Internet, has been widely used around the world by entrepreneurs to build businesses based on sound human values and principles that takes into account the numerous benefits and virtues offered to the people, planet, and profits.
\end{abstract}

Keywords: IQ, EQ, SQ, business model canvas, education, mosque, ICT, CSR.

\section{Introduction}

This paper is based on the combination of three aspects, namely providing well-balanced education, utilizing technology particularly ICT and with the entrepreneurship spirit in creating value and solution for school children holistic development. Education in Islam is regarded as a process that completely nurtures the individual as al-Attas (2012) confirms, 'Education should aim at the balanced growth of the total personality of Man through the training of Man's sprit, intellect, rational self, feelings and bodily senses such that faith is infused into the whole of his personality'.

Entrepreneurship is the willingness to take risks and develop, organize and manage a business venture in a competitive global marketplace that is constantly evolving. Entrepreneurs are pioneers, innovators, leaders and inventors. They are at the forefront of technological and social movements - in their fields, in their forward thinking, in their desire to push the envelope. They are dreamers and most importantly are doers (Bainbridge Graduate Institute, 2014). Meanwhile, technology is a body of knowledge that is applied to create tools, build up skills and extract or collect materials. In addition, it is the application of science (the combination of the scientific technique and material) to meet an aim or solve a problem.

\section{Project Background}

This paper proposed the development and establishment of a tuition program named e-Maarah Tuition Portal, focusing on school children who are going to take UPSR, PBSMR, SPM examinations in Malaysia. Our proposed tuition program adopted the blended mode of education, combining the conventional approach which is face-to-face and utilizing ICT and Internet. This tuition program will be conducted in mosques. This is one of the major attraction of e-Maarah Tuition Portal where school children will "imaarah" (or live up) the mosques atmosphere. In the context of "Rahmatan li'l-Alamin" (or Mercy to all mankind), this portal shall provide selected educational contents and exercises for free. The focus targeted audiences are the Muslim school children, but it is also open to non-Muslims regardless of their economic status and background.

\section{Problem Statement}

Nowadays, mosques are being used only for religion purposes such as congressional prayer, religious sermons and Friday prayers. Looking back at the history of Prophet Muhammad PBUH, a mosque is the center of the administration where education, virtue and value building, meetings, societal event, and it is also a place for people to consult with Prophet Muhammad PBUH if they have any problems and questions to be asked. The potential of reviving the strategic roles of mosques through tuition programs is high. 
Secondly, most of the existing tuition centers charged high fees for their tuition programs, depending on student's level of study and the number of subjects taken. Through our observations, these existing tuition programs focus only on academic excellence, thereby giving less priority to ethics, virtues and values factors. The mode of existing education is normally based on one way communication where teachers teach and students learn through listening and doing assignments. Hence, the opportunity of providing a new two-way communication through blended education is now feasible and available.

Thirdly, according to UNESCO's definition of literacy where it refers to the ability to identify, understand, interpret, design, communicate, and learn to use printed and written materials relating to a variety of contexts (Fong Peng Chew, 2012). The current illiteracy rate of students in Malaysia is 7\% as compared to 9\% in 2005. Malaysian Quality of Life Index (MQLI), launched in 2011 by the Minister in the Prime Minister's department, said that 8,831 pre-school classes had been established in government-aided schools last year, which had enabled more than 175,000 children to attend pre-school. In aligning with the objectives of MQLI in achieving a low rate of illiteracy in Malaysia, establishing initiatives such as e-Maarah Tuition Portal would be encouraged. Hence, the focus of this paper would be on school children who are going to take major Malaysian public examinations i.e. the Year 6, Form 3 and Form 5 students.

\section{Objective}

The main objective for this paper is to propose the creation of e-Maarah Tuition Program - blending the IQ, EQ, SQ-focused education, ICT and entrepreneurship - to build businesses based on sound human values and principles that take into account the numerous benefits and virtues offered to the people, planet, and profits. The anticipated outcome from this Program is that the school children will be able to balance between the worldly and the Hereafter matters, sustaining excellence and fairness in life. The second objective is that the students are able to use technology and make wise of it. In achieving this objective, e-Maarah Tuition Portal shall provide free and premium educational contents, notes and quizzes where school children can access anywhere, any time. Regarding the location of the tuition center as well as the delivery channel to school children, it is proposed to use network of mosques so as to revive their strategic roles including becoming the center and network of excellent in education. At the same time, e-Maarah Tuition Program shall be able to generate sustainable revenue and profit from affordable students. From an Islamic perspective, this Program can be one of the sources of "Rahmatan li'l-Alamin" or "Mercy to all the worlds" and making the world a better place by expanding the culture of virtues especially amongst school children.

\section{Literature Review}

The definition of Social Entrepreneurship is doing social business in helping the underprivileged community, where there are two (2) kinds of business objectives. The first objective is for personal gain and another is for the purpose of helping others. The first type of business is to maximize profit for the owners with little or no consideration of contributing to others. The other type is utilizing profit for the benefits of others and nothing for the owners except for the pleasure of serving humanity such as the Orphanage, Poor and Disabled.

According to Burhan et al (2013), the Orphanage, the Poor and the Disabled are the usual groups of people that are highly attended to, both from the community as well as the Malaysian government. This is in line with one of the Quran's verses that mentioned "..... and give away wealth out of love for Him (Allah) to the near kin and the orphans and the needy and the wayfarer and the beggars and ..." (2:177). The Orphans can be categorized as children with the age range of 1 year to 16 years. According to UNICEF, orphan children is defined as children who have lost both parents and also those who have lost a father but have a surviving mother or have lost their mother but have a surviving father. The Poor can be considered as people who have difficulty in getting their basic needs such as food, clothes, accommodation and insufficient income in enhancing the quality of their life. The state of being Poor can sometime be attributed to the lack of education and job opportunities, where with proper education given they can support themselves and lead a better life. According to the New Straits Times, since 2010 more than 90,043 low-income families have benefited from the 1Azam anti-poverty programme. The Disabled is classified as any person who is unable to obtain for him/her, fully or partially, the normal requirements of an individual and/or is unable to participate fully in the community due to shortcomings either physically or mentally and whether it occurred since birth or later in life. Rehabilitation service is provided to help the disabled to be independent and subsequently enabling them to reach the maximum potential in all aspects of their lives which are suitable to their abilities. The statistic has shown that in 2010, the population of disabled people was 2.8 million out of 28 million Malaysia population.

The Mosque had many uses during the early times of Islam - as a headquarters for the state, a hospital, a shelter for the poor and needy, an information point, a place of relaxation and siesta, as well as being a place of prayer and contemplation, and guiding the Muslims on how to live based on Islam, beginning from an individual to the family, community, country and international (Wahid et al, 2011). "The word mosque (masjid) is grounded on three Arabic words (Wahid et al, 2011): misjad that literally means to bow down; masjad which 
connotes a man who touched his forehead during prostration and misjid simply put is a small mat" (Khan, 2012). To concur with the forgoing, it is pertinent to add here that the etymology of the word mosque originated from the word 'masjid' which simply put implies the place where people prostrate to God; hence it is referred to the House of Allah (Bait Allah), which is a place where only Allah is worshipped and remembered: "In houses, which Allah has ordered to be raised, in them His Name is glorified in the mornings and in the afternoons or the evenings" (Quran, 24:36). Thus, the Mosque represents the establishment of a Muslim community; it is the nucleus that creates the characteristics of the Muslim society (Khalit, 2011) as well as center-of excellence for the ummah. In addition, the Mosque in Islamic history was the focal point where political, social, and religious activities were holistically blended and implemented in realizing the meaning of "Mercy to all the worlds" well-being in this world as much as the life hereafter. Thus, the role of mosques has always been instrumental in the social-moral, economical, and political uplift of the Muslim community (Religion.Islam, 2008). It is therefore incumbent that the Muslim Ummah should endeavor to reinvigorate and revive the roles of the mosques in every ramification of life (Habiba Hamid et al, 2013).

The Malaysian National Education Philosophy can be said as an on-going effort towards further developing the potential of individuals in a holistic and integrated manner, so as to produce individuals who are intellectually, spiritually, emotionally and physically balanced and harmonious based on a firm belief in and devotion to God (Cassidy Lisut, 2012). To achieve the vision of the Malaysian Philosophy of Education, a wellbalance education consisting of IQ, EQ and SQ is needed. The Emotional Intelligence (EQ) term was first used by Mayer and Salovey (1990) which refers to the ability to recognize feelings of self and other people's feelings as a guide to think and behave. Intelligence quotient or IQ as an ability to solve an objective problem alone, can be used to make a person to be competent enough (Brody and Brody, 1976). Spiritual Quotient (SQ) refers to the degree to which an individual can demonstrate Spiritual Intelligence and 'Spiritual Capital' refers to a company's ability to generate wealth through Spiritual Intelligence.”(Danah Zohar, 2004). "The transformative power of SQ distinguishes it from IQ and EQ. IQ primarily solves logical problems. EQ allows us to judge the situation we are in and behave appropriately. SQ allows us to ask if we want to be in that situation in the first place. It might motivate us to create a new one.” (Danah Zohar \& Ian Marshall, 1999).

These three elements are integrated and inter-dependence. It is imperative and crucial for a person to have these three elements in their live. So, it is timely for school children to learn, understand, practice and develop these elements so that they can have an excellence, fair and balance life style. In this era of globalization and borderless world, it is observed that most of school children are focusing only on Intelligence Quotient (IQ) and they are not able to capitalize on their Emotional Quotient (EQ) potential. This creates a situation where there are children that have problems in their social life as well as having difficulties to express their feelings and opinions. Although they have achieved a high level of academic merit, it does not mean that they are completely excellence because there is no balance between the IQ and EQ. The same problem happen with the Spiritual Quotient (SQ), where people seem to neglect their spiritual need or knowledge and it affected their moral value. It is a shame for us to know that our younger generations lack moral value and religion knowledge that enable them to lead a life of a "khalifah"(or leader) in this world.

Education should not be a concern for parents and teachers only, rather it is a part of the community duties to help these children in acquire knowledge and virtue in an affordable way. Nowadays, corporate social responsibility (CSR) has become a trend in the corporate world. It is fashionable for organizations, especially large ones, to make CSR part of their overall business strategy. The triple bottom line that lies behind CSR efforts - the three Ps of people, profit and planet - sees organization getting involved not just in charitable works but also contributing to the betterment of the communities they are based in as well as the communities of their stakeholders (The Star Special, 27 April 2014).. All these contribute to their brand awareness and to profits. Of course, it does not hurt to be seen as a benevolent and philanthropic entity instead of a greedy corporate giant. The proposed project meant to implement the three Ps concepts by providing people (student) an affordable tuition fees, gaining more profit as more and more customer are attracted by the low rate fess offered and benefit the environment by using mosques as the tuition centre, as it is more safer for students to come to mosque for their tuition.

Tuition is an extra class initiated by teachers or qualified person to give extra lesson or knowledge to students so that they can have more understanding about certain subjects. Also, it can be an alternative way for the students to revise what they had learnt at schools. There are few types of tuition services provided including through tuition centers and private home based tuitions. By definition, tuition center means the center is located at a specific location in which students have to travel from their home to the tuition center. Meanwhile, private home based tuition has a similar concept of tutoring which mean the tutor or the teacher will come to the student's house and teach them in the form of one to one session. Both of the tuition program used traditional method, face-to-face education, where no form of technology are being deployed in their teaching and learning process.

Entrepreneurship is the practice of consistently converting good ideas into profitable commercial ventures (Peter F. Drucker, 1985). As being said by Sir Richard Branson, the entrepreneurs are contrarian value 
creators. They see economic value where others see heaps of nothing. And they see business opportunities where others see only dead ends. Technology is not necessarily "hi-tech", indeed does not always have to be technical. Technology is simply defined as applications of knowledge to human work. Technopreneurship is by a large part, still under entrepreneurship category. The difference is that technopreneurship is either involved in delivering an innovative hi-tech product or makes use of hi-tech in an innovative way to deliver its products/services to consumers.

Tuition center is located at a fixed location where students have to travel to the center to learn. According to the research, most of the tuition center charged quite a high fee for the students in the range of RM 30 to RM 35 per subject. The fees are fixed to each student education level. Students that learn in the tuition center vary from Year 1 to Form 5. Subjects covered by this Tuition Program are the basic subjects for UPSR student, PBSMR student and also SPM student. Private home based tuition is similar to tutoring concept in which the teacher has to go to the student's house and teach them in a one to one method. Referring to our research, fees for this type of tuition is the highest since the tutor has to travel to the student's house where they need to cover the travel bill. Fees charged for this private tuition start between the ranges of RM 25 to RM 40 per hour.

\section{Conceptual Solution}

e-Maarah Tuition Program is a new concept of tuition where technology is deployed within the teaching and learning process. The technology, in the form of a portal, is used to distribute online content, notes and quizzes. The targeted audience is Muslim students that come from Year 6, Form 3, and Form 5. Nonetheless, it is also open to students from other races and religions. The location for this tuition will be at mosques by collaborating with Jabatan Agama Islam Selangor (JAIS) and Malaysian Innovation Agency. As for the fees, it is proposed to charge RM 30 for each student/subject. The subjects offered for UPSR students are English, Mathematics, Science, and Malay while as for PMR students, the subjects offered include Mathematics, English, Science, Malay and History. Other than that, the subject provided for SPM student are Biology, Physic, Chemistry and Accounting and Additional mathematics. Aside from all above, it is propose to provide free spiritual classes for students so that they can have the access to gain Islamic knowledge. This is due to the fact that people today are focusing more on the academic value rather than the spiritual value.

Figure 1 show the 9 blocks of Business Model Canvas (BMC) based on the business proposed. Figure 2 shows the functionality of channels and key resources from the 9 blocks of BMC. Business Model Canvas is a simple tool for designing Innovative Business Models. Business Model Canvas is a simple graphical template describing the nine essential components: Customer segments, value propositions, channels, customer relationships (such as self service or personal assistance), revenue streams, resources, activities, partnerships, and costs. (Alexander Osterwalder, 2012). The following are the proposed 9 blocks of BMC for e-Maarah Tuition Program:

\section{Customer segments}

The business proposed focus on school children because at this age, knowledge can be easily accepted and practiced as long as it is provided with good teaching and teaching process. Based on the research, result shows about $50 \%$ of human intelligence capability occurred when a child is four years old, $80 \%$ has occurred with rapid development of brain tissue as young as eight years old and reached its peak when the child is 18 years old, and after that even the nutrition has been repaired, it is hardly to bring effect on cognitive development. The targeted audiences are school children that come from an average financial family background. As for the poor students, the tuition service is free.

\section{Customer relationship}

For the customer relationship, this business needs to sustain a good customer relationship with students and parents. There will be interactive activities between teachers, students and parents. Activities may in the form of games so as to make students feel more relax so that they are able to keep focus on the next learning session.

\section{Channels}

There are a number of ways on how the teaching method will be delivered to the students. One of the ways is in the classroom where it involved the interaction between teachers and students. Face to face method of teaching is one of the best ways for student to gain knowledge. There are many instances in which face-to-face instructor-led training is still the best solution for teach (Daniel R. Tobin, 2010). Other than that, online learning or e-learning can complement the face-to-face teaching system. Online learning as a subset of distance learning facilitates the learning process through the internet. As a special form of educational process or practice, 
however, the uncertainties of online learning remain to be solved "regarding how, and in what ways, technology can enhance the teaching/learning process, particularly at a distance" (Phipps \&Merisotis, 1999).

\section{Value proposition}

It is believed that the value proposition offered by the proposed tuition center can attract many parents to send their children to tuition center. It offers an affordable price that cannot be resists by families from varies financial background. Affordable can be defined as being within the financial means of most people (MerriamWebster Dictionary). Fees charge is RM30 for all subjects per student. In addition to that, this fee is fixed on other level of students, which means all of the students will be paying the same price regardless of which level they are. In addition, it offers free Islamic classes to boost up the student's knowledge about the Islamic knowledge. In a hadith narrated Abdullah ibnAmribn al-'As: The Apostle of Allah (PBUH) said: "Command your children to pray when they become seven years old, and beat them for it (prayer) when they become ten years old; and arrange their beds (to sleep) separately". Following the "sunnah" (tradition or way), it also will establish an Islamic classes where in these classes, the student will be teach on how to perform prayer in a proper way. A part of that, there will be also a Quranic lesson to the students, alongside with "tadabbur" (reciting) and Quranic "tafseer" (translating) session.

Technology can be defined as the branch of knowledge that deals with the creation and use of technical means and their interrelation with life, society, and the environment (Dictionary.com). Most of the education institutions nowadays teach in a traditional method, which is face-to face, ignoring the fast growing technology. Realizing this opportunity, it offers a technology-based teaching to engage students. In addition, e-Maarah Tuition Portal is a on-line platform where all contents, notes and quizzes can be easily stored, managed and retrieved online.

\section{Key activities}

The main reason on doing this project is to give knowledge to students by through e-Maarah tuition program. This is also can be categorized as the alternative ways for them to gain more knowledge and at the same time have an advance learning about the subject that they learnt from their daily school. Other than that, the tuition proposed to teach the student Islamic knowledge such as how to perform prayer, read and understanding the meaning of verses or a chapter from the Al-Quran so that, they can have a balance knowledge of the world and hereafter. Moreover, the tuition is providing physical activities during leisure time so that they can manage to release their tension and at the same gain more knowledge. The activities will be conducted by the tuition teachers, and it also will be an interactive activity which means that the students can have an interaction with the teachers. It can also make them to be more comfortable with the teachers and make the learning process more attractive.

\section{Key resources}

In most of the teaching and learning program that are going to serve, teachers are the crucial entity to make the service success. Teachers will demonstrate communication and interpersonal skills as they relate to interaction with students (Teacher Duties and Responsibilities). Meanwhile, notes and laptops are tools to facilitate the learning and teaching process. The teacher will provide free notes for the students in order to study in class. Besides using the traditional method of teaching, portal is also act as the platform for the teacher to gain profit. Portal is used by the teacher to enhance the student's learning skill. The portal will provide extra learning material for student to boost up their learning desire. For example, free notes of the topic will be given to the students online. Then, after the student has revised the notes, they will attempt to answer the quizzes questions free of charged. One of the purpose of this portal is to gain profit from it, the profit is attain by providing some of the extra notes and quizzes exercise that need to be pay. Teachers will provide extra notes and extra exercise that more advance from the free notes and exercises. Figure 3 shows the e-Maarah tuition portal as a medium for the online teaching method. It shows the screen shot from the E-Maarah tuition's portal. From this portal, user can download notes and quizzes for according to their level. Other than that, they can also register themselves to join this program by filling up the form in the Get Involved section. The portal also provides news updated in the portal such as the notes and quizzes. Along from that, user can also download free Islamic software.

\section{Key partners}

To ensure the success of e-Maarah Tuition Program, key partners and collaborators are needed that include the following government organizations:

\section{Jabatan Agama Islam Selangor (JAIS)}

This is to get the permission to use the mosques area as our centers and channels to conduct the tuition activities, delivering knowledge and creating virtues for the school children. 
Ministry of Science, Technology and Innovation (MOSTI)

MOSTI's mission is : "To drive and manage STI for socioeconomic growth by intensifying creativity and innovation; strengthening market driven R\&D; sourcing and diffusing new technology; developing and attracting talent; deepening STI awareness; and strengthening collaborations and partnerships". (MOSTI, $13^{\text {th }}$ May 2014), (refer to Appendix I). MOSTI offered few funding programs under ICT section such as Techno Fund, Human Capital Development Fund and so on so forth. TechnoFund is a grant scheme which aims to stimulate the growth and successful innovation of Malaysian enterprises by increasing the level of R\&D and its commercialization. The scheme provides funding for technology development, up to pre-commercialization stage, with the commercial potential to create new businesses and generate economic wealth for the nation.

Mosque

The proposed tuition is also proposing to the mosque in area of Selayang to give permission on using the facilities in the mosque to conduct this project.

\section{Cost structure}

To come up with this service, some preparation are needed in order to overcome the costs issue that are going to be faced. Maintenance of the laptops and website, cost for printing the notes in class, monthly payment of WiFi and salary for teachers, and also books that are going to be used by teachers.

\section{Revenue streams}

In order to gain revenue, normal students need to pay monthly fee with the amount of RM 30 per month per subject taken. For students who want to have an advanced notes and exercise, they can have it by purchasing it online from the portal. The activity of selling tit-bits products such mineral water and sandwiches for students will be helped to gain more revenue. Meanwhile, to benefit the skills in designing, the team will offer a design services such as poster, bunting, banner, t-shirt and so forth.

\section{Conclusion}

It proposed that e-Maarah Tuition Program to be implemented, as a "Proof-of-Concept" with the collaboration of MOSTI and JAIS, in two mosques in Gombak/Selayang area. In future, this Program will be rolled-out to other mosques and conducted by other universities students. Therefore, this Program will be expanded to the grass root levels because it involves many mosques (network of mosque). To wrap up, this paper has shown that there is a need for education centers to teach the students about the 'akhirah' or hereafter matters and how students should master both the worldly knowledge and 'akhirah' knowledge. In the context of an Islamic perspective, e-Maarah Tuition Program is building businesses based on sound human values and principles that takes into account the numerous benefits and virtues offered to the people, planet, and profits

\section{References}

[1]. Abu Productive (2010). Investing our time (Our life's most precious assets) Part 2 of 2

[2]. http://productivemuslim.com/investing-our-time-our-lifes-most-precious-assets-part-2-of-2/

[3]. Agensilnovasi Malaysia (AIM)innovation.my

[4]. Alexander Osterwalder(2012) Forbes

[5]. http://www.forbes.com/sites/tedgreenwald/2012/01/31/business-model-canvas-a-simple-tool-for-designing-innovative-businessmodels/

[6]. Allan Gullinao (2013). Malaysia Educational System.

[7]. http://www.slideshare.net/Rhaiine/malaysia-written-report

[8]. Bainbridge Graduate Institute (2014). What is Entrepreneurship?

[9]. http://www.bgi.edu/changing-business/what-is-entrepreneurship/

[10]. Cassidy Lisut (2012). Malaysian Philosophy of Education.

[11]. http://www.slideshare.net/cassidylisut/malaysian-philosophy-of-educationCountry's literacy rate above 93 per cent (2012).New Straits Times.

[12]. http://www.nst.com.my/nation/general/country-s-literacy-rate-above-93-per-cent-1.93593Curriculum Specifications (2007).Ministry of Education Malaysia.

[13]. http://www.google.com/url?sa=t\&rct=j\&q=malaysian $\% 20$ education $\% 20$ philosophy\&source=web\&cd=2\&sqi=2\&ved=0CCsQFjAB \&url=http\%3A\%2F\%2Fweb.moe.gov.my\%2Fbpk\%2Fsp_hsp\%2Fsains\%2Fkbsr\%2Fsc_yr6_eng.pdf\&ei=SF8gULnJImtrAfDqoGADg\&usg=AFQjCNHSxrdeL0uO6RmR1Qedp_HqzMI7_Q\&bvm=bv.62788935,d.bmk

[14]. Danah Zohar, Spiritual Capital,(2004). Wealth we can live by.

[15]. http://www.google.com.my/url?sa=t\&rct=j\&q=\&esrc=s\&source=web\&cd=5\&cad=rja\&uact=8\&ved=0CEcQFjAE\&url=http $\% 3 \mathrm{~A} \%$ 2F\%2Fwww.bkconnection.com\%2Fstatic\%2FspiritualintelligencePR.pdf\&ei=MktFU83PBoSKrgfS4IHQAQ\&usg=AFQjCNG4GR UGVOTHSMhZAtD2S8Azp0T3gQ\&bvm=bv.64507335,d.bmk

[16]. Danah Zohar \& Ian Marshall,(1999) Spiritual Intelligence-the Ultimate Intelligence

[17]. http://books.google.com.my/books/about/SQ.html?id=RFLdGwAACAAJ\&redir_esc=y

[18]. Daniel R. Tobin (2010). Ten Advantage of face-to-Face Instructor-Led Training.

[19]. http://nextgenerationofleaders.com/nextgenerationofleaders_033.html

[20]. Dictionary.com

[21]. http://dictionary.reference.com/browse/technology 
[22]. Fong Peng Chew (2012). Literacy among the Secondary Schools Students in Malaysia

[23]. http://www.google.com/url?sa=t\&rct=j\&q=low\%20literacy\%20in $\% 20$ malaysia\&source=web \&cd=1\&cad=rja\&uact=8\&ved=0CCQ QFjAA\&url=http\%3A\%2F\%2Fwww.ijssh.org\%2Fpapers\%2F168-

A10042.pdf\&ei=0HcgU7fOK4iNrgeRo4H4Ag\&usg=AFQjCNH3GyqFFF7ak98CVOkUEodRpCS3BA\&bvm=bv.62788935,d.bmk

[24]. Hamid, H., Khairuddin, N. D., Al-amodi, Y., Ahmad Dahlan, A. R., \& Ahmad H Osman, R. (2013). MyMosqueNet2Cloud

Collaborative System: A network of mosques towards eradicating poverty in Malaysia. American Academic \& Scholarly Research Journal, 5(5).

[25]. Haryanto, S.Pd(2012). PentingnyaPendidikanAnakUsiaDini

[26]. http://belajarpsikologi.com/pentingnya-pendidikan-anak-usia-dini/

[27]. Jabatan Agama Islam Selangor (JAIS)

[28]. www.jais.gov.myMalaysian EducationEducation System of Malaysia.Ministry of Higher Education Malaysia.

[29]. http://www.mohe.gov.my/educationmsia/education.php?article=system

[30]. Merriam Webster

[31]. http://www.merriam-webster.com/thesaurus/affordableNational Literacy Policies (2002).

[32]. http://www.accu.or.jp/litdbase/policy/mys/

[33]. Peter F. Drucker, (1985) Innovation and Entrepreneurship

[34]. http://www.google.com.my/url?sa=t\&rct=j\&q=\&esrc=s\&source=web\&cd=5\&cad=rja\&uact=8\&ved=0CEkQFjAE\&url=http\%3A\% 2F\%2Fdruckersociety.at\%2Frepository\%2Fscientific\%2FPearl.pdf\&ei=CU1FU9H3JMiArgeu6oCoDw\&usg=AFQjCNF6ilXsHTP9 b2q8xVOpNeBfsKyxig\&bvm=bv.64507335,d.bmk

[35]. Phipps \&Merisotis(1999) A Comparative Study of the Effectiveness of an Online and Face-to-Face Technology ApplicationsCourse in Teacher Education

[36]. http://www.google.com.my/url?sa=t\&rct=j\&q=\&esrc=s\&source=web\&cd=1\&cad=rja\&uact=8\&ved=0CCcQFjAA\&url=http\%3A\% 2F\%2Fwww.sicet.org\%2Fjournals\%2Fijtt1\%2FspecialIssue\%2Fhongbo.pdf\&ei=dVFFU-

rQGsS4rgfKwICwBQ\&usg=AFQjCNE4A4UTJMc3Z0wS0eHoDrDzEspAfg\&bvm=bv.64507335,d.bmk

[37]. Renee Smith and Teresa Franklin, Chia-Ling Kuo. A Comparative Study of the Effectiveness of an Online and Face-to-Face Technology Applications Course in Teacher Education.

[38]. Saleh, B., Ma-Key, N., Dahlan, A., Rahman, A., \& Osman, R. A. H. (2013, March). MyMukim2Cloud Collaborative System. In Information and Communication Technology for the Muslim World (ICT4M), 2013 5th International Conference on (pp. 1-7). IEEE.

[39]. Sunan Abu Dawud . Search Truth. http://www.searchtruth.com/book_display.php?book=2\&translator=3\&start=28\&number=0485

[40]. Tan Sri Nor Mohamed Yakcop (2012). Country's literacy rate above 93 per cent, News Strait Times

[41]. http://www.nst.com.my/nation/general/country-s-literacy-rate-above-93-per-cent-1.93593

[42]. Teacher duties and responsibilities, http://www.ware.k12.ga.us/Handbook/Secondary\%20Pages/Teacherdutyandrespon.htm

The Business Model Canvas

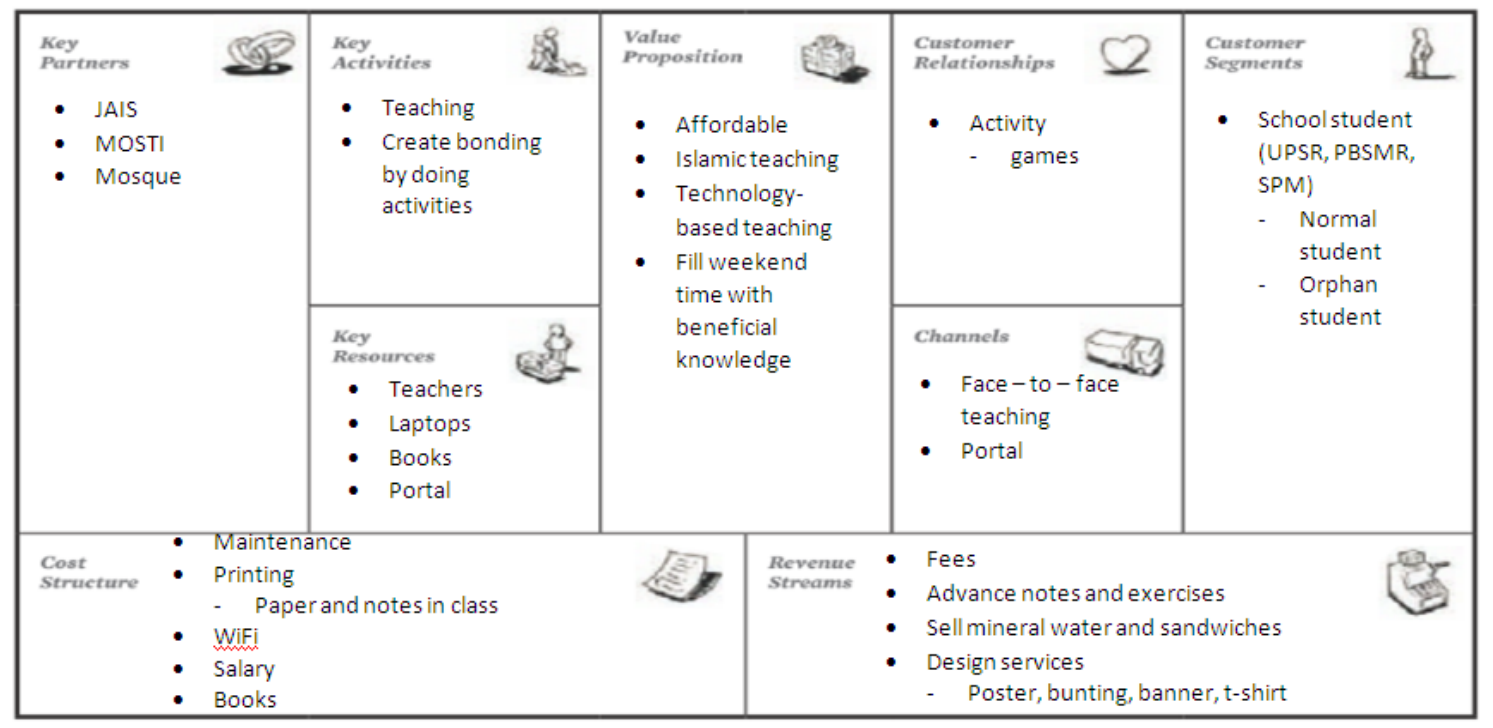

Figure 1: Business Model Canvas 
The Business Model Canvas

\begin{tabular}{|l|l|l|l|l|}
\hline $\begin{array}{l}\text { Key } \\
\text { Partners }\end{array}$ & $\begin{array}{l}\text { Key } \\
\text { Activities }\end{array}$ & $\begin{array}{l}\text { Customer } \\
\text { Relationships }\end{array}$ & Customer \\
Segments
\end{tabular}

Figure 2: Business Model Canvas (Channels \& Key Resources)

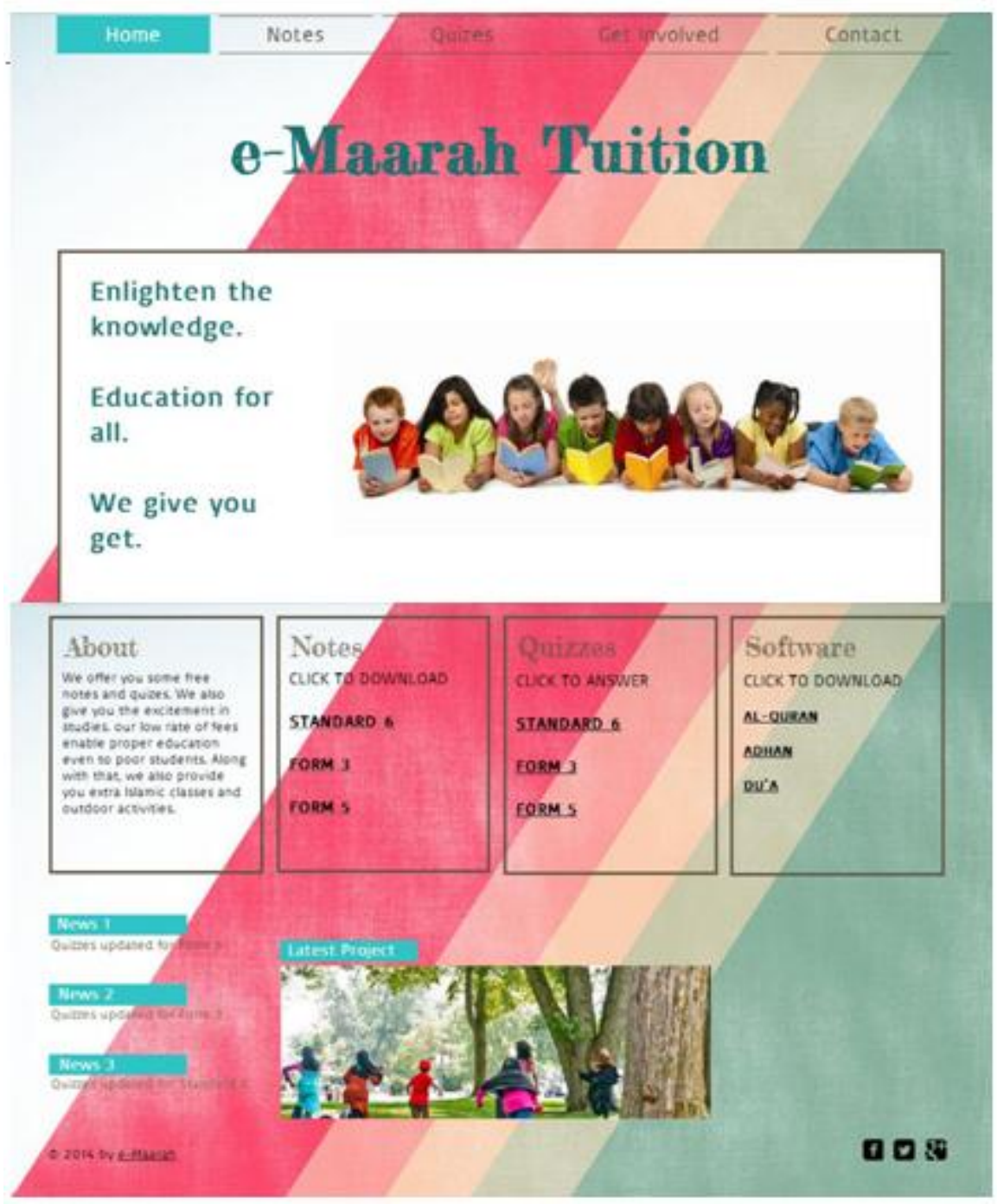

Figure 3: e-Maarah tuition portal 


\section{Introduction}

ICT Cluster, which is under the coordination of the ICT Policy Division, is geared towards achieving the nation's ICT targets to accelerate realization of Malaysia's aspirations to become a knowledge-based economy.

\section{Objectives}

- To spearhead the development of ICT industry and indigenous technologies and capabilities

- To build and sustain national ICT ecosystem and enabling environment; and

- To support efforts to make Malaysia a Global ICT Hub for wealth creation, knowledge generation and social well-being

\section{Functions}

- Drive and coordinate ICT Cluster [consisting of Multimedia Development Corporation Sdn. bhd. (MDeC), MIMOS Berhad, CyberSecurity Malaysia and .my Domain Registry];

- Act as Secretariat for National IT Council (NITC) and formerly the secretariat to National Cyber Security Advisory Committee (NaCSAC) and National Cyber Security Coordination Committee (NC3)

- Manage e-Content Fund and Demonstator Application Grant Scheme (DAGS)

- Coordinate technical evaluation and monitor implementation of ICT projects under ScienceFund, TechnoFund, InnoFund, Human Capital Development, Brain gain and National Science Fellowship (NSF);

- Coordinate ICT Cluster participation in promoting and enhancing ICT awareness at the Federal, State and international level; and

- Manage international affairs related to ICT including bilateral cooperation at regional and international level and monitor issues such as Global Alliance ICT or Development (GAID), eASEAN, International Telecommunication Union (ITU), World Congress on Information and Technology (WCIT) and Free Trade Agreement (FTA).

Figure 4: MOSTI's homepage 